\title{
Lift Force of Airfoil (NACA 0012, NACA 4612, NACA 6612) With Variation of Angle of Attack and Camber: Computational Fluid Dynamics Study
}

\author{
Mariza D. Ardany ${ }^{1}$, Paken Pandiangan ${ }^{2}$ and Moh. Hasan $^{3}$ \\ ${ }^{1}$ Kajian Komputasi Aplikatif, Jalan Simpang Panji Suroso No.100, Polowijen, Kec. Blimbing, \\ Kota Malang 65126, Jawa Timur, Indonesia \\ ${ }^{2}$ Universitas Terbuka Indonesia, Jalan Cabe Raya Pondok Cabe 15418, Jakarta, Indonesia \\ ${ }^{3}$ Departement of Mathematics, Faculty of Mathematics and Natural Sciences, Universitas \\ Jember, Kalimantan Street No. 37, Jember 68121, Indonesia \\ amarizaardany22@gmail.com
}

\begin{abstract}
Airfoil is a cross section from air plane wings can affect aerodynamic performance to lift force $\left(F_{L}\right)$. The lift force generated by airfoil has different values due to several external and internal factors, including angle of attack, flow rate and camber. To find the lift force of airfoils with different cambers and variations angle of attack and then flow rate can use computational fluid dynamics simulation. Computational fluid dynamics is simulation on a computer that can complete systems for fluid, heat transfer and other physical processes. This research using computational fluid dynamics simulation performed by SolidWorks, with NACA airfoil type which has different camber NACA 0012, NACA 4612 and NACA 6612. The angle of attack used in research was $0^{\circ}, 4^{\circ}, 8^{\circ}, 12^{\circ}, 16^{\circ}$ and $20^{\circ}$. Flow rate used in research was $20 \mathrm{~m} / \mathrm{s}, 40 \mathrm{~m} / \mathrm{s}, 60 \mathrm{~m} / \mathrm{s}, 80 \mathrm{~m} / \mathrm{s}$ and $100 \mathrm{~m} / \mathrm{s}$. From this research will be the bigger camber can produce a greater force lift. In addition, the greater airfoil flow rate can produce a greater force lift. This research also that the connection between force lift with coefficient lift $\left(C_{L}\right)$ is nonlinear quadratic form.
\end{abstract}

Keywords: Airfoil NACA, Force Lift, Angle of Attack, Flow Rate, Computational Fluid Dynamics.

\section{Introduction}

Airfoil is a cross section of the wing that result from the perpendicular of the aircraft wing [1]. Airfoil which is often used in the aviation is asymmetric airfoil, because it has a geometry with aerodynamic characteristics that can increase the value of the lift coefficient $\left(C_{L}\right)$ [2]. The lift force $\left(F_{L}\right)$ of an airplane is affected by difference air pressure around the airfoil [3]. Difference pressure around the airfoil, due to differences in flow rate at the upper and lower airfoil. Another factor that affects lift force $\left(F_{L}\right)$ on an airplane is angle of attack. Angle of attack is the angle between chord line and direction of the wind. Chord line is a line that connects leading edge and trailing edge of the airfoil [3].

The development of technology in order to analyze aerodynamic character and experimental methods. The development of aerodynamics technology conducting experiments on airfoil configurations to find out specifications, get inaccurate result and require large cost in the testing process. Another problem that appear in the experimental method is less flexible during the result-taking process because it only uses tunnels for airfoil testing. Overcome the shortcoming of the experimental method in analyzing airfoil characteristics, the simulation method is solution. The simulation method offers convenience in observing or predicting variations on the value of physical quantities. Simulation method is a method that can be used to analyze airfoils with accurate result and low operating cost when compared to experimental 
methods [4]. One of the analysis system simulation methods used to analyze airfoil characteristics is CFD [5,6]. Computational Fluid Dynamic (CFD) is a computer - based for simulating fluid systems, head transfer and other physical processes. The principle of CFD is to solve fluid dynamics problems based on certain formula, such as Navier-Stokes [7].

Research with the CFD simulation method was conducted to determine force lift $\left(F_{\mathrm{L}}\right)$ from the effect of thickness, angle of attack and another factor of the airfoil. Research on airfoils using the CFD simulation method was carried out by Guerrero (2009) about the effect of variation camber on airfoil performance in the NACA 0012, 2212, 2412, 4412, 2612, 4612, 6612 dan Selig S122. Maximum airfoil thickness at NACA is $12 \%$ from chord line with difference variation camber. The result of these research indicates that the NACA 6612 has a greater lift coefficient value than NACA 0012. NACA 6612 is an asymmetrical airfoil shape because it has certain camber thickness, while NACA 0012 is symmetrical airfoil because it doesn't have a camber thickness value. The result in this research indicate that the greater thickness of the camber, the greater lift force $\left(F_{L}\right)[8]$.

Other research on airfoils using the CFD simulation method was carried out by Jain et al. (2015) about the characteristics of the Reynolds number on an airfoil on the effect of variation in the angle of attack and flow rate. This study a variation of angle of attack, namely $0^{\circ}, 4^{\circ}, 8^{\circ}, 12^{\circ}$ and $16^{\circ}$. This research, it can be concluded that the greater the Reynolds number, the smaller lift coefficient $\left(C_{L}\right)[9]$.

The weakness of previous research is that only focuses on effect of the angle of attack on the resulting lift force $\left(F_{\mathrm{L}}\right)$. The result of research used a CFD simulation method and experimental method little that analyzed the effect of variations in angle of attack and flow rate to determine resulting force lift $\left(F_{L}\right)$. Previous research only focused on one or two variables such as the variation in angle of attack with flow rate in one type of airfoil or camber variations with angle of attack. Research that discusses the effect of the variations in the angle of attack and flow rate with various types of NACA airfoils on one topic is still rare, so that is the basis for this research. Focus of the research that determine the effect of variations in angle of attack and flow rate on various types of NACA airfoils on the resulting force lift $\left(F_{L}\right)$.

Airfoil that will be used in this research is NACA (National Advisory Committee for Aerobatics) symmetry and asymmetry airfoil type. The airfoil that will be used in this research are NACA 0012, NACA 4612 and NACA 6612. This research was conducted to determine how the characteristics of the airfoil lift force $\left(F_{L}\right)$ on NACA airfoil with different cambers. From this research, two values will be used to determine the characteristics of the airfoil force lift $\left(F_{L}\right)$, namely the value of the force lift $\left(F_{L}\right)$ and coefficient lift $\left(C_{L}\right)$. From tis research it is also known ow the connect between forces lift $\left(F_{L}\right)$ and coefficient lift $\left(C_{L}\right)$. This research uses variations in the angle of attack and flow rate, these variations are used to determine how the effect of force lift $\left(F_{L}\right)$ characteristics of the NACA airfoil.

\section{Theoretical Background}

\section{NACA Airfoil}

Airfoil is a form of aircraft wing that can generate aerodynamic lift. The force lift $\left(F_{L}\right)$ is generated from a cross section perpendicular to the wing of the airplane. Airfoil is a two - dimensional 
aircraft wing shape [10]. This study uses an airfoil NACA four - digit series. Airfoil NACA series four or so called NACA XXXX, developed in 1932 with various airfoil shapes. The first digit of a NACA series four airfoils is the percent of maximum camber to chord. The second digit is one tent of the maximum position of the camber with respect to the cord of the leading edge [11]. The last two digits of a series four NACA airfoil represent the percent thickness of the airfoil with the chord. Airfoil has sections with different functions. The airfoil parts can be seen in Figure 1.

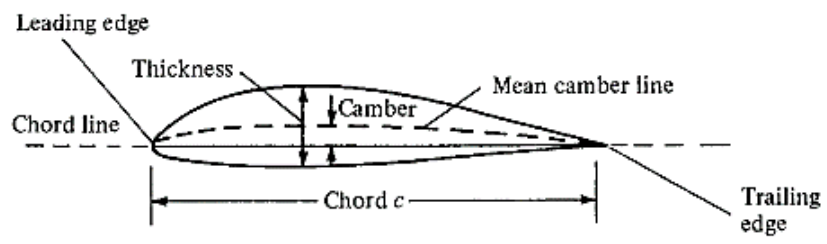

Figure 1. Part of the airfoil [2]

Explanations of Figure 1:

- leading edge is the front of the airfoil,

- trailing edge is the back of the airfoil,

- chord $\mathrm{c}$ is the distance between leading edge and training edge,

- chord line is a straight line connecting the leading edge and training edge,

- mean camber line is an equal dividing line between the upper and lower airfoil,

- thickness is the maximum distance between the upper and lower surface of the airfoil,

- camber is the maximum distance of the chord line with chamber line [12].

Airfoil is a geometric shape of an airplane wing in the fluid flow which produces a lift that is greater than drag. The lift of large airfoil is greater than the drag on fluid flow, causing the airfoil to be chosen in airplane wing components because it is very efficient [13]. The lift of an airfoil is formed because there is a difference in pressure between the upper and lower surfaces of the airfoil, which gives rise to the resultant force perpendicular to the direction of the fluid flow [14]. The difference in pressure between the front and rear of the airfoil that causes a resultant force that is parallel to the arrival of the fluid flow is usually called drag. Forces acting on the plane can be seen from Figure 2.

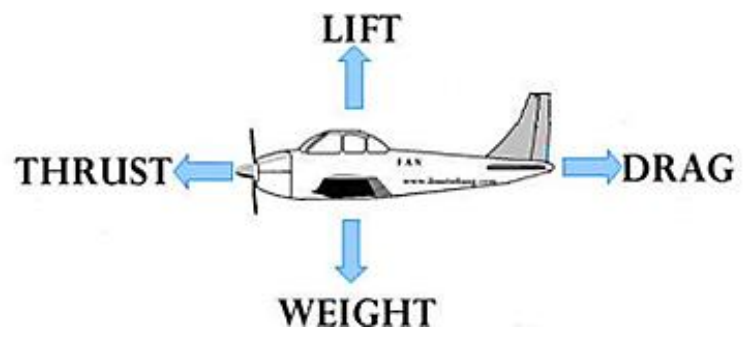

Figure 2. Forces acting on the plane [2] 
The forces acting on the plane are:

- Thrust is the force generated by the engine (power plant).

- Drag is the force that pulls the airplane backwards.

- Weight is the force that comes from the combined weight of the aircraft's payload, such as crew, fuel and cargo or baggage.

- Lift is the force perpendicular to the direction of flight through the center of lift of the wing [11].

\section{Coefficient lift $\left(C_{L}\right)$}

Force lift $\left(F_{L}\right)$ of the airfoil depends on the coefficient of lift $\left(C_{L}\right)$ which is influenced by size of the camber and angle of attack. Greater value of the angle of attack causes the fluid flow above the airfoil surface to from dead air behind airfoil. Fluid flow moving in a circle opposite to the free stream flow is reversed flow. The split fluid flow is due to the viscosity effect. The separation of the fluid flow causes a reduction in lift or coefficient lift $\left(C_{L}\right)$, and cause the amount of drag due to pressure drag, this condition is called a stall. Stall is a decrease in force lift $\left(F_{L}\right)$, which is caused by an increase in angle of attack or an increase in angle of attack that exceeds the critical angle of attack which allows a slowdown on the underside of the aircraft wing [15]. Drag is force whose direction is parallel to the direction of fluid flow [16]. Drag in the from of skin friction drag $\left(F_{D F}\right)$ arising from the presence of shear stress and pressure drag $\left(F_{D P}\right)$ arising from fluid pressure. Profile drag is the sum of skin friction drag $\left(F_{D F}\right)$ and pressure drag $\left(F_{D P}\right)$ shown from Figure 3.

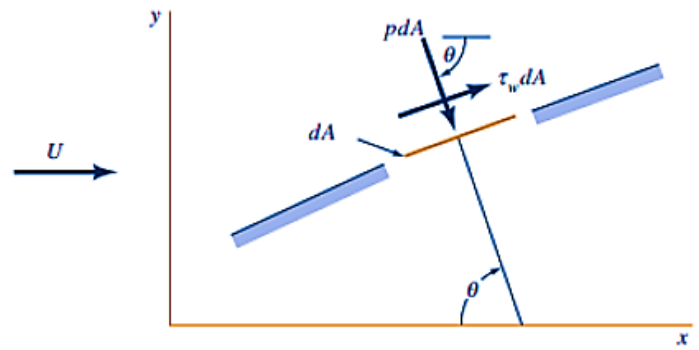

Figure 3. Profile drag [17]

The resultant of this forced will produce the following equation:

$d F_{y}=-(P d A) \sin \theta+\left(\tau_{w} d A\right) \cos \theta$

The component of the force towards the $y$ - axis is the force lift $\left(F_{L}\right)$, can be formulated as follows:

$L=\int d F_{y}=-\int P \sin \theta d A+\int \tau_{w} \cos \theta d A$

Lift force $\left(F_{L}\right)$ can be expressed as a dimensionless number. Lift force $\left(F_{L}\right)$ is a component of the force perpendicular to the direction of free stream flow [16]. The equation for the coefficient lift $\left(C_{L}\right)$ can be written as follows: 
$C_{L}=\frac{L}{\frac{1}{2} \rho U^{2} A}$

Explanation of Equation (1), (2) and (3):

- $\quad L$ is lift force $(\mathrm{N})$

- $\tau_{w}$ is the direction of fluid flow that passes through the object

- $\rho$ is the density of the fluid $\left(\mathrm{kg} / \mathrm{m}^{3}\right)$

- $A$ is surface of the object through which the fluid passes $\left(\mathrm{m}^{2}\right)$

- $C_{L}$ is coefficient lift

\section{Computational Fluid Dynamics (CFD)}

Computational Fluid Dynamics (CFD) is one of the existing technological developments to produce information about fluid flow. CFD simulation method used in solving fluid problems using numerical methods. The CFD method is widely used because it can reduce costs in analyzing a system [11]. CFD method can also reduce the time in data collection, when compared to experimental methods [18].

The geometry in CFD is quite complex. Fluid flow in CFD will be divided into grid and nodes elements, by using that simulates partial differential equations. The advantage of using the CFD method is that it can be used as a more practical calculation, making it easier for differential operations [19]. The simulation using the CFD method is shown in Figure 4.

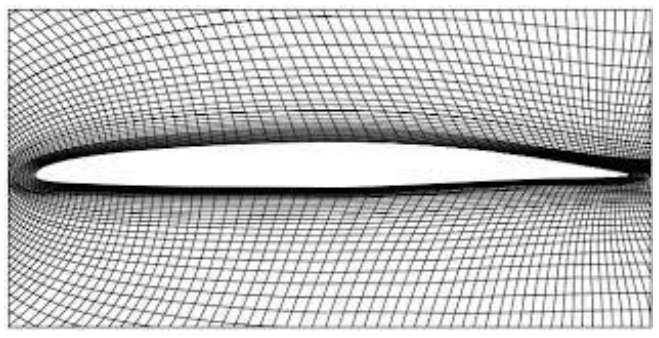

Figure 4. CFD simulation method with meshing airfoil NACA [19]

The mathematical solution to solving CFD simulation method uses Newton's second lawa of motion combined with Stoke's stress law, yields three momentum equations for velocity in direction $x_{j}(j=1,2,3)$. The CFD mathematical solution using the RANS equation also takes into account the Reynolds number value, which aims to determine whether the fluid flow is laminar of turbulent. Distribution of the RANS equation can be used to solve CFD simulation method by taking into account the fluid flow formed. The CFD simulation method solution also uses several input parameters related to the Reynolds and RANS equation. These parameters include flow rate, temperature, density, pressure, viscosity and length of fluid flow through the object. This parameter will effect the value of the resulting Reynolds number and indicate the type of fluid flow formed. These parameters in the CFD simulation method [20].

\section{Research Methods}


This research method includes design and simulation using SolidWorks software. This simulation is done sing an airfoil NACA 0012, NACA 4612 and NACA 6612. The variations used in this simulation are angle of attack and flow rate. The angle of attack used in this simulation is $0^{\circ}, 4^{\circ}, 8^{\circ}, 12^{\circ}, 16^{\circ}$ and $20^{\circ}$. The flow rate used in this simulation is $20 \mathrm{~m} / \mathrm{s}, 40 \mathrm{~m} / \mathrm{s}, 60 \mathrm{~m} / \mathrm{s}, 80$ $\mathrm{m} / \mathrm{s}$ and $100 \mathrm{~m} / \mathrm{s}$. this variation used to determine the characteristics of the NACA airfoil at each camber based on resulting of force lift $\left(F_{L}\right)$ and coefficient lift $\left(C_{L}\right)$.

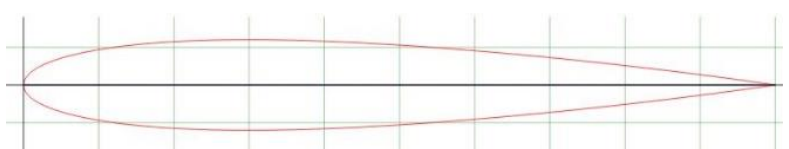

Figure 5. NACA 0012 design with a chord line length of $1 \mathrm{~m}$

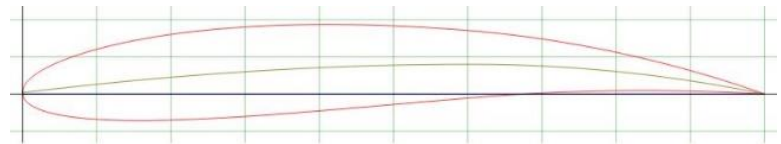

Figure 6. NACA 4612 design with a chord line length $1 \mathrm{~m}$

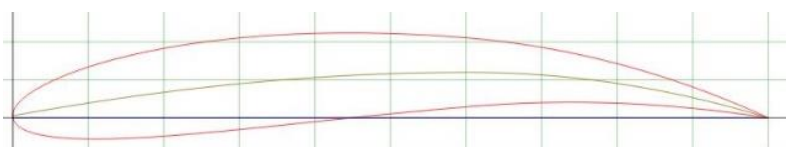

Figure 7. NACA 6612 design with a chord line length $1 \mathrm{~m}$

Table 1. Boundary Parameter

\begin{tabular}{lll}
\hline \hline Parameter & Value & Unit \\
\hline Temperature & $300^{[21]}$ & $\mathrm{K}$ \\
Atmosphere pressure & $101325^{[21]}$ & $\mathrm{Pa}$ \\
Density of air & $1.225^{[21]}$ & $\mathrm{kg} / \mathrm{m}^{3}$ \\
Air viscosity & $1.7894 \times 10^{-5}[21]$ & $\mathrm{m}^{2} / \mathrm{s}$ \\
Chord line length & 1 & $\mathrm{~m}$ \\
Level initial mesh & $4^{[22]}$ & - \\
Minimum gap size & $0.767660947^{[22]}$ & $\mathrm{m}$ \\
\hline \hline
\end{tabular}

The simulation process with the CFD method:

1. Design the airfoil geometry on SolidWorks software.

2. Enter the boundary parameter on SolidWorks software.

3. Simulated for each airfoil with variations in angle of attack and flow rate.

4. Plot the result in the form of force lift $\left(F_{L}\right)$ and coefficient lift $\left(C_{\mathrm{L}}\right)$ in Excel software. 


\section{Results}

\section{Effect of Angle of Attack and Flow Rate Variations on te Force Lift $\left(F_{L}\right)$ and Coefficient Lift $\left(C_{L}\right)$ of the NACA Airfoil}

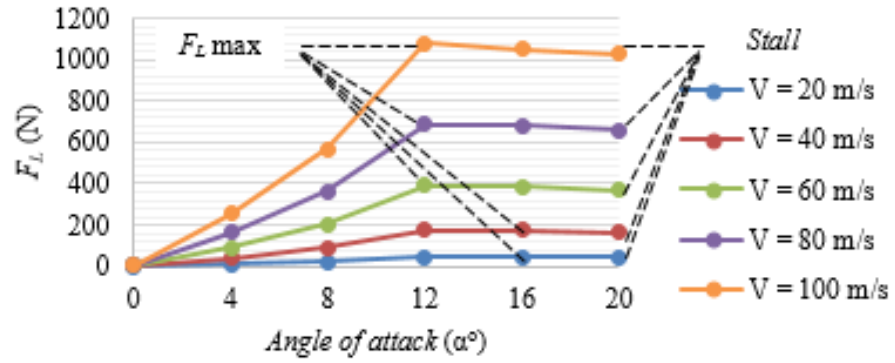

Figure 8. Graph $\left(F_{L}\right)$ with $A O A$ and flow rate on NACA 0012

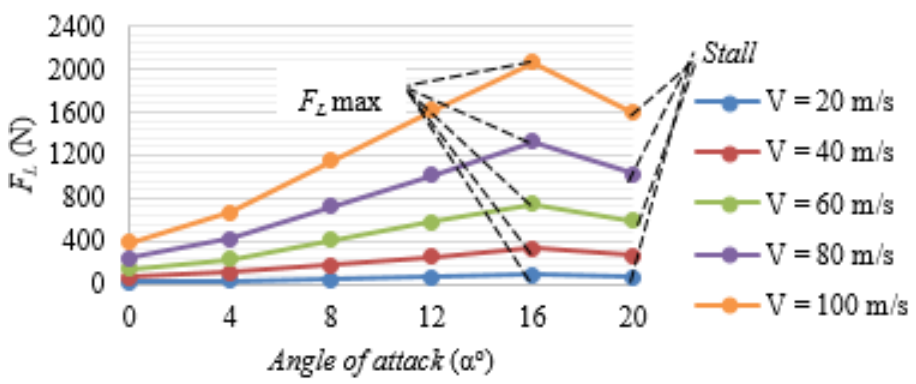

Figure 9. Graph $\left(F_{L}\right)$ with AOA and flow rate on NACA 4612

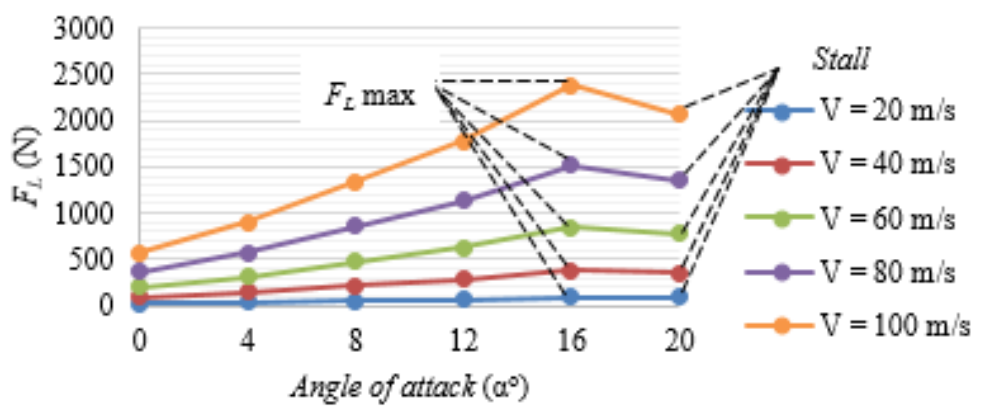

Figure 10. Graph $\left(F_{L}\right)$ with $A O A$ and flow rate on NACA 6612

Influence of variation of angle of attack and flow rate on an airfoil at NACA 0012, NACA 4612 and NACA 6612 to the value of force lift $\left(F_{L}\right)$, based on Figure 8, Figure 9 and Figure 10 that is, the greater the angle of attack and flow rate, the greater the lift, but the angle of attack is too large in value that exceeds the critical angle of attack or produces maximum force lift $\left(F_{L \max }\right)$, it can cause the NACA airfoil to experience a stall. Stall is a condition where the lift will decrease after experiencing the maximum lift, this is because the enlarged angle of attack exceeds the 
angle of attack which shows the maximum lift.

The resulting value of maximum force lift $\left(F_{L \max }\right)$ for each NACA airfoil will be different. The difference in the value of maximum force lift $\left(F_{L \text { max }}\right)$ for each NACA airfoil is different due to the effect of different camber values. The greater camber, the greater force lift $\left(F_{L}\right)$. The camber value of the NACA airfoil used in this research as a different value, such as NACA 0012 has a camber value 0. Airfoil NACA 4612 has a camber value in the first digit is 0,04 and 0,4 chord camber position. Airfoil NACA 6612 has camber value in the first digit is 0,06 and 0,6 chord camber position.

The maximum force lift $\left(F_{L \max }\right)$ values of the NACA 0012 airfoil at flow rates of $20 \mathrm{~m} / \mathrm{s}, 40 \mathrm{~m} / \mathrm{s}$, $60 \mathrm{~m} / \mathrm{s}, 80 \mathrm{~m} / \mathrm{s}$ dan $100 \mathrm{~m} / \mathrm{s}$ are $43,4 \mathrm{~N} ; 172,8 \mathrm{~N} ; 388,5 \mathrm{~N} ; 687,4 \mathrm{~N}$ and $1077,5 \mathrm{~N}$ with the angle of attack at an flow rate of $20 \mathrm{~m} / \mathrm{s}$ to $40 \mathrm{~m} / \mathrm{s}$ is $16^{\circ}$ while at an flow rate of $60 \mathrm{~m} / \mathrm{s}$ to $100 \mathrm{~m} / \mathrm{s}$ is $12^{\circ}$. The maximum force lift $\left(F_{L \text { max }}\right)$ values of the NACA 4612 airfoil at flow rates of $20 \mathrm{~m} / \mathrm{s}, 40$ $\mathrm{m} / \mathrm{s}, 60 \mathrm{~m} / \mathrm{s}, 80 \mathrm{~m} / \mathrm{s}$ and $100 \mathrm{~m} / \mathrm{s}$ is $81,1 \mathrm{~N} ; 328,7 \mathrm{~N} ; 741,6 \mathrm{~N} ; 1320,9 \mathrm{~N}$ and 2067,9 $\mathrm{N}$ with angle of attack is $16^{\circ}$. The maximum force lift $\left(F_{L \max }\right)$ values of the NACA 6612 airfoil at flow rates of $20 \mathrm{~m} / \mathrm{s}, 40 \mathrm{~m} / \mathrm{s}, 60 \mathrm{~m} / \mathrm{s}, 80 \mathrm{~m} / \mathrm{s}$ and $100 \mathrm{~m} / \mathrm{s}$ are $92,0 \mathrm{~N} ; 374,7 \mathrm{~N} ; 845,9 \mathrm{~N} ; 1516,3 \mathrm{~N}$ and 2384,1 $\mathrm{N}$ with angle of attack is $16^{\circ}$.

The maximum force lift $\left(F_{L \max }\right)$ performance obtained on theNACA 0012 airfoil based on the result obtained is $1077,5 \mathrm{~N}$ with an angle of attack and flow rates of $12^{\circ}$ and $100 \mathrm{~m} / \mathrm{s}$. The maximum force lift $\left(F_{L \text { max }}\right)$ performance obtained on theNACA 4612 airfoil based on the result obtained is $2067,9 \mathrm{~N}$ with an angle of attack and flow rates $16^{\circ}$ and $100 \mathrm{~m} / \mathrm{s}$. The maximum force lift $\left(F_{L \text { max }}\right)$ performance obtained on theNACA 6612 airfoil based on the result obtained is 2384,1 Nwith an angle of attack and flow rates $16^{\circ}$ and $100 \mathrm{~m} / \mathrm{s}$. Based on the maximum force lift $\left(F_{L}\right.$ max) generated by the airfoil that as the largest lift are NACA 6612 because it as the largest camber. Camber is two leading digits of the NACA four - digit series. The symmetry of an airfoil will depend on the camber value. Camber which as a value of 0 , is type of symmetrical airfoil, such as NACA 0012, while camber which has a value like NACA 4612 and NACA 6612 is a type of asymmetric airfoil.

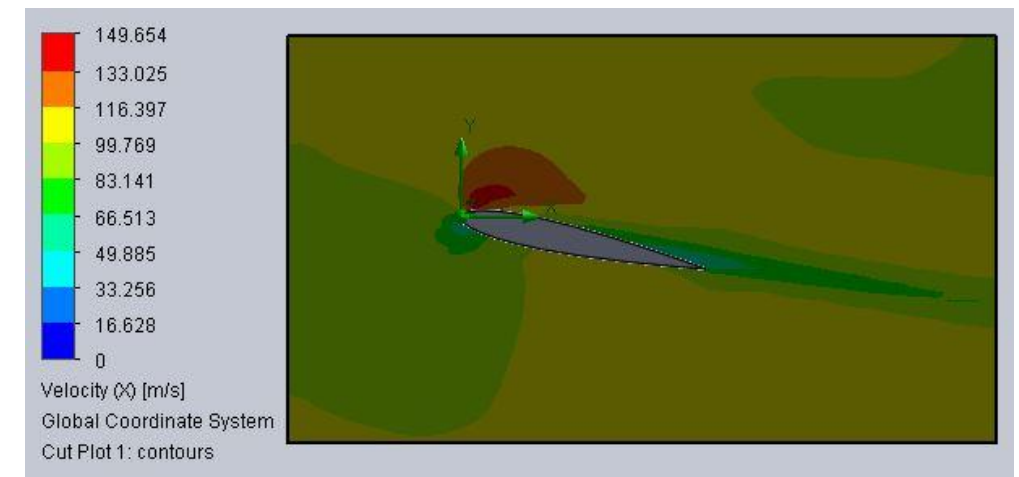

Figure 11. Distribution of the flow rate around the airfoil NACA 0012 with angle of attack $12^{\circ}$ and flow rate $100 \mathrm{~m} / \mathrm{s}$ 


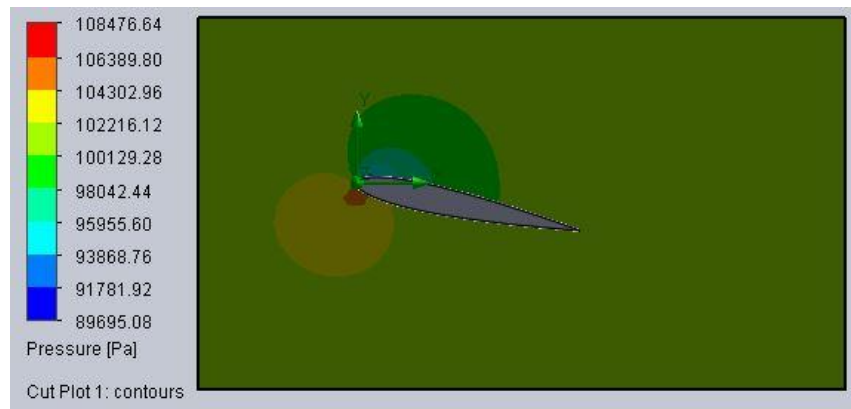

Figure 12. Distribution of pressure around the airfoil NACA 0012 with angle of attack $12^{\circ}$ and flow rate $100 \mathrm{~m} / \mathrm{s}$
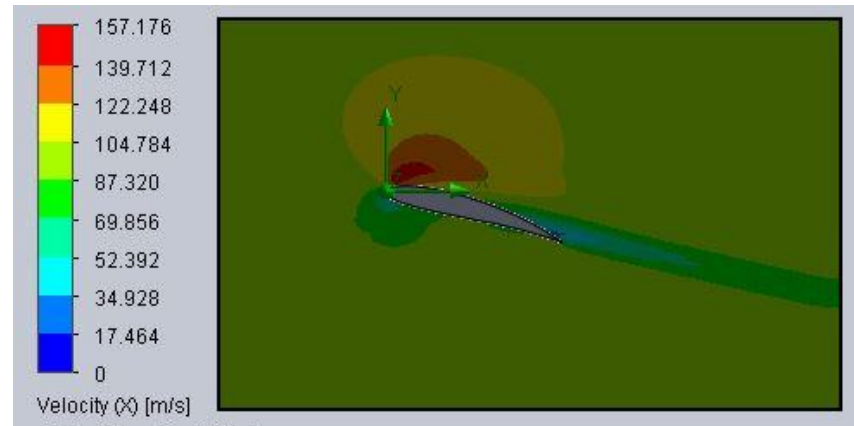

Figure 13. Distribution of the flow rate around the airfoil NACA 4612 with angle of attack $16^{\circ}$ and flow rate $100 \mathrm{~m} / \mathrm{s}$

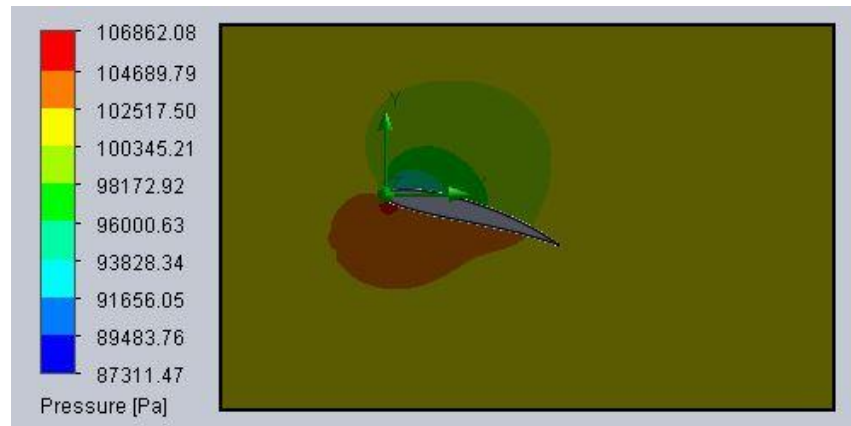

Figure 14. Distribution of pressure around the airfoil NACA 4612 with angle of attack $16^{\circ}$ and flow rate $100 \mathrm{~m} / \mathrm{s}$ 


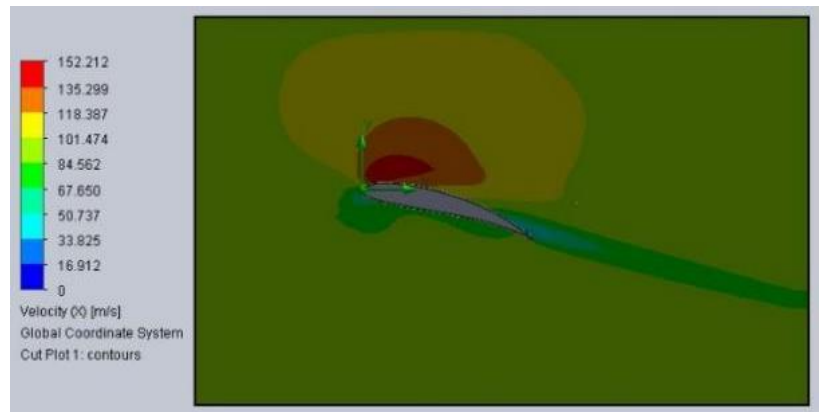

Figure 15. Distribution of the flow rate around the airfoil NACA 6612 with angle of attack $16^{\circ}$ and flow rate $100 \mathrm{~m} / \mathrm{s}$

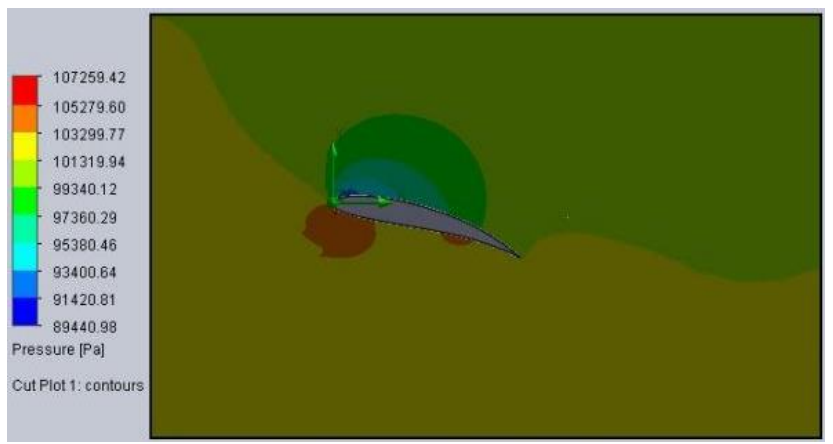

Figure 16. Distribution of pressure around the airfoil NACA 6612 with angle of attack $16^{\circ}$ and flow rate $100 \mathrm{~m} / \mathrm{s}$

The effect of variations in flow rate in this research can affect the lift generated for each airfoil. Figure 11, Figure 13 and Figure 15 show the distribution of flow rate around the airfoil at a certain angle of attack. Result on Figure 11, Figure 13 and Figurer 15 it can be seen that the flow rate flowing at the upper of tr airfoil surface has a greater value, when compared to the lower of airfoil. The difference in flow rate at the upper and lower of the airfoil surface is in accordance with Bernaulli's law of lift on the aircraft. Because the difference in flow rate at the upper of the airfoil causes the lower pressure of the airfoil to be greater than the pressure on the upper surface of the airfoil. This statement is in accordance with the result of our research indicated by Figure 12, Figure 14 and Figure 16. Because the pressure below the airfoil surface is greater than the upper of airfoil surface, it causes lift, this statement is in accordance with the result Figure 12, Figure 14 and Figure 16. Thus, if the flow rate passing through an airfoil is greater, the lower pressure airfoil surface will be even greater when compared to the upper surface of the airfoil. So that the greater flow rate passing through an airfoil, the greater force lift $\left(F_{L}\right)$ generated by an airfoil. 


\section{Connect Coefficient of lift $\left(C_{L}\right)$ with Force Lift $\left(F_{L}\right)$}

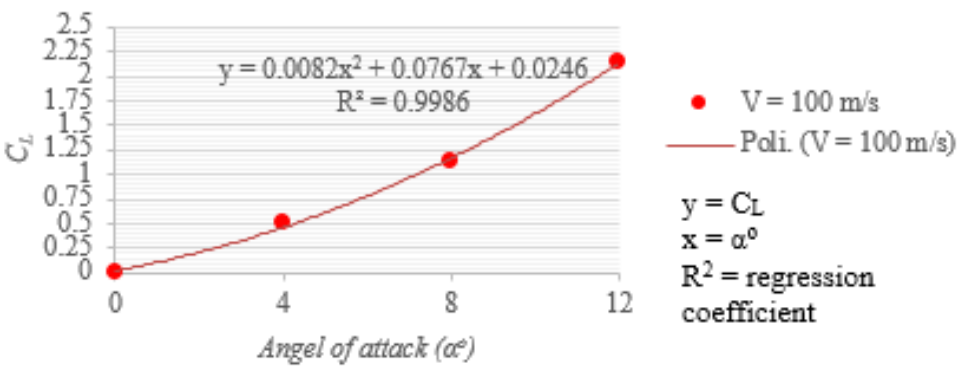

Figure 17. Graph nonlinear $C_{L}$ with AOA on airfoil NACA 0012

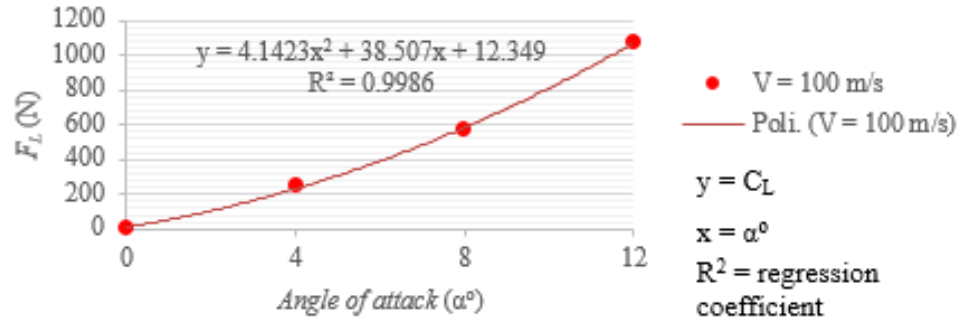

Figure 18. Graph nonlinear $F_{L}$ with AOA on airfoil NACA 0012

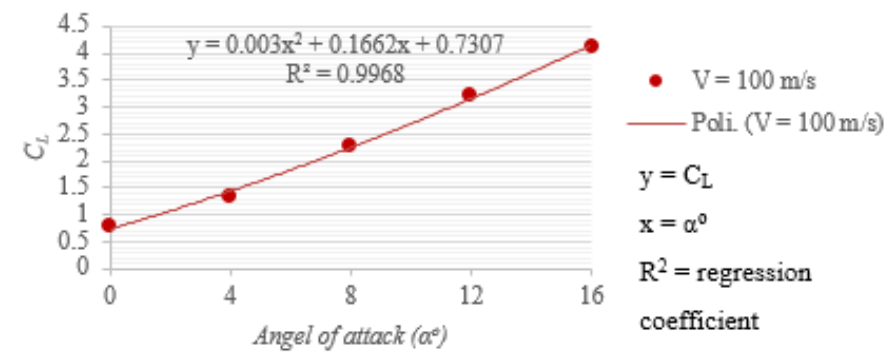

Figure 19. Graph nonlinear $C_{L}$ with AOA on airfoil NACA 4612

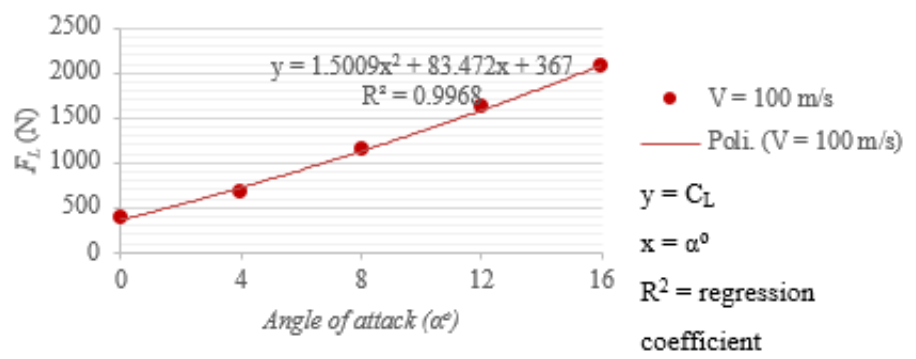

Figure 20. Graph nonlinear $F_{L}$ with AOA on airfoil NACA 4612 


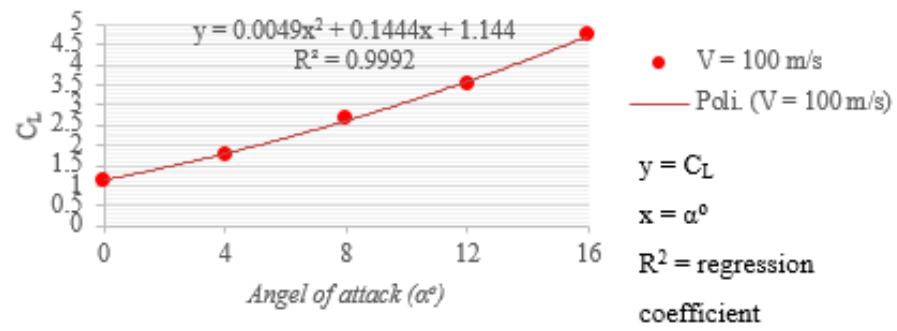

Figure 21. Graph nonlinear $C_{L}$ with AOA on airfoil NACA 6612

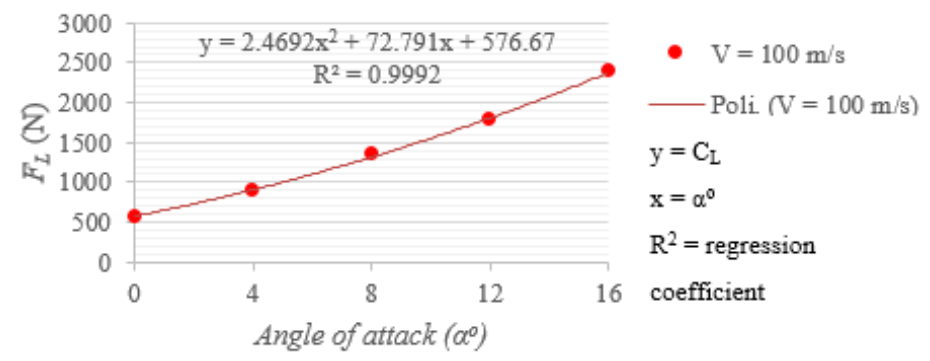

Figure 22. Graph nonlinear $F_{L}$ with AOA on airfoil NACA 6612

The result of the research on the connect between the coefficient of lift $\left(C_{L}\right)$ and the force lift $\left(F_{L}\right)$ in this research can be said to be quadratic nonlinear, this is because the regression coefficient value shown is close to 1 , the coefficient of lift $\left(C_{L}\right)$ and force lift $\left(F_{L}\right)$, have a regression coefficient value, the same one. The regression coefficient is the value of graph showing how the graph is getting more linear or nonlinear wen it approaches 1 . The regression coefficient values shown in the results of this research are close to 1, for nonlinear quadratic graph. So, it can be concluded that the connect coefficient of lift $\left(C_{L}\right)$ and force lift $\left(F_{L}\right)$ is nonlinear quadratic.

\section{Conclusion}

The effect of angle of attack on NACA airfoils for different cambers is that the greater the angle of attack, the greater resulting force lift $\left(F_{L}\right)$, but the angle of attack is too large in value that exceeds the critical angle of attack or produces maximum force lift $\left(F_{L \text { max }}\right)$, it can cause NACA airfoil stalled. The NACA airfoil that produces the greatest maximum lift force there is NACA 6612 , at angle of attack $16^{\circ}$ and flow rate $100 \mathrm{~m} / \mathrm{s}$. The effect of flow rate on NACA airfoils for various cambers is that the greater flow rate, the greater force lift $\left(F_{L}\right)$. Connect coefficient of lift $\left(C_{L}\right)$ and force lift $\left(F_{L}\right)$ is nonlinear quadratic.

\section{References}

[1] E. Houghton, P. Carpenter., et al, 2013, Aerodynamics for Engineering Students, Amsterdam: Elsevier, chapter 6.

[2] Z. Wei, C. Wan., et al, 2016, Geometrical Effects on the Airfoil Flow Separation and Transition, International Journal Computers \& Fluids, vol. 116, page 60-70.

[3] J. John, 2010, Fundamental of Aerodynamics, New York: McGraw-Hill. 
[4] A. A. Yassin and A. M. A. Elbashir, 2011, Simulation Around Airfoil NACA 4412, Thesis, Faculty of Engineering, University of Khartoum, Sudan.

[5] R. Anggraeni, 2019, Effect of Angle of Attack on Pressure and Lift Coefficient of ONERA OA206 Wing Model Using Computational Fluid Dynamics Method, Computational and Experimental Research in Materials and Renewable Energy (CERiMRE), Volume 2, Issue 2, page 81-97.

[6] S. A. Ayudia, A. Arkundato, and L. Rohman, 2020, Study of Vortex Generator Effect on Airfoil Aerodynamics Using the Computational Fluids Dynamics Method, Computational and Experimental Research in Materials and Renewable Energy (CERiMRE), Volume 3, Issue 2, page 68-74.

[7] H. Lomax, D. W. Zing., et al, 1999, Fundamental of Computational Fluid Dynamics, Amerika: University of Toronto.

[8] J. E. Guerrero, 2009, Effect of Cambering on the Aerodynamic Performance of Heaving Airfoils, Bionic Enginering, vol 6, page $398-407$.

[9] S. Jain, N. Sitaram., et al, 2015, Effect of Reynolds Number on Aerodynamics of Airfoil with Gurney Flap, International Journal of Rotationing Machinery, vol. 2015, page 1-10.

[10] Y. Wibisono, G. Nugroho., et al, 2013, Studi Karakteristik Aliran Tiga Dimensi dan Perpindahan Panas pada Cascade Airfoil dengan Pengaruh Clearance, Teknik Pomits, vol. 2, no. 1 , page $110-115$.

[11] M. Mulyadi, 2014, Analisis Aerodinamika pada Sayap Pesawat Terbang degan Menggunakan Software Berbasis Computational Fluid Dynamics (CFD), Artikel Universitas Gunadarma, page 1-13.

[12] M. F. Hidayat, 2014, Analisa Aerodinamik Airfoil NACA 0012 dengan Ansys Fluent, Kajian Teknologi, vol. 10, no 2, page $83-92$.

[13] M. M. Lubis, 2012, Analisa Aerodinamika Airfoil NACA 2412 pada Sayap Pesawat Model Tipe Glider dengan menggunakan Software Berbasis Computational Fluid Dinamic untuk Memperoleh Gaya Angkat Maksimum, E - Dinamis, vol. 2, no. 2, page 23 - 33.

[14] T. Nurcahyadi and Sudarja, 2008, Pengaruh Lokasi Ketebalan Maksimum Airfoil Simetris Terhadap Koefisien Angkat Aerodinamisnya, IImiah Semesta Teknika, vol.11, no. 1, pp. $110-124$.

[15] J. C. Kewas and M. Ali, 2020, Analisis Akibat Perubahan Kecepatan Aliran Udara Dan Sudut Serang pada Airfoil NACA 0015 dalam Wind Tunnel Sub Sonic, Jurnal Frontiers, vol.2, no. 1, pp. $71-79$.

[16] R. Ridha, 2017, Studi Numerik Karakteristik Aliran Tiga Dimensi Di Sekitar Airfoil NACA 0012 dengan Backward Swept Angle $0^{\circ}, 15^{\circ}$, dan $30^{\circ}$, skripsi, Fakultas Teknik Mesin, Institut Teknologi Sepuluh Nopember, Surabaya, Indonesia.

[17] A. Sayma, 2009, Computational Fluid Dynamics, New York: Venus Publishing ApS. 
[18] B. R. Muson, D. F. Young., et al, 2009, Fundamental of Fluid Mechanics, United States of America: Jhon Wiley \& sons.

[19] F. M. White, 1998, Fluid Mechanics, United States: McGraw-Hill Series in Mechanical Engineering.

[20] A. W. Date, 2005, Introduction to Computational Fluid Dynamic, United Kingdom: Cambridge University Press.

[21] M. Kavadiya, 2013, CFD Analysis of Pressure Coefficient for NACA 4412, International Journal of Engineering Trends and Technology (IJETT), Vol. 4, No. 5.

[22] A. M. Gofar, 2018, Pemilihan Sudut Pasang Airfoil NACA 2412 pada Tail UAV dengan Menggunakan Software Berbasis Computational Fluid Dynamic untuk Memperoleh Gaya Angkat Optimal, skripsi, Dept. Teknologi Industri., Universitas Islam Indonesia., Yogyakarta, Indonesia. 